\title{
ANALISIS PRESTASI BELAJAR SISWA PELAJARAN EKONOMI, STATUS SOSIAL EKONOMI ORANG TUA DAN BIMBINGAN BELAJAR (STUDI PADA SMA NEGERI 10 KOTA TANGERANG)
}

\author{
${ }^{1}$ Dadang Saepuloh \\ ${ }^{1}$ FKIP Ekonomi \\ ${ }^{1}$ Universitas Islam Syekh Yusuf \\ Email:dsaepuloh@unis.ac.id
}

\begin{abstract}
This study aims to determine the effect of parental socioeconomic status and tutoring on students' learning achievement of economic subjects in class XI of the social studies program at SMA 10 Tangerang. The sample in this study were 54 students in SMA 10 Tangerang. This research is ex-post facto research. The variables of this study are economic learning achievement, socioeconomic status, and tutoring. Data collection techniques use questionnaires and documentation. The analytical method used is multiple regression analysis. From the results of the study, the following conclusions are obtained: (1) socioeconomic status does not affect the learning achievement of Economics subjects which is indicated by a sig value of 0.184 more than 0.1. (2) learning guidance has an effect on economic learning achievement which is indicated by a sig value of 0.030 smaller than 0.1. (3) socioeconomic status and tutoring have a positive effect on economic learning achievement which is indicated by a sig value of 0.046 smaller than 0.1 . R2 value of 0.113 means that $11.3 \%$ of the learning achievement of Economics subjects is explained by socioeconomic status and tutoring. While $88.7 \%$ is explained by other factors not examined in this study.
\end{abstract}

Keywords: Learning Achievement, Socio-Economic Status, Tutoring 


\section{A. PENDAHULUAN}

\section{Latar Belakang}

Pendidikan merupakan persoalan yang penting bagi kemajuan bangsa. Dengan pendidikan maka dapat dilahirkan manusia-manusia yang mampu membangun diri sendiri dan masyarakat sekitarnya yang sesuai dengan bunyi Undang-Undang Pendidikan Nasional tahun 2003 pasal 3, bahwa Pendidikan Nasional bertujuan mengembangkan potensi peserta didik agar menjadi manusia yang beriman terhadap Tuhan Yang Maha Esa, berakhlak mulia, sehat, berilmu, cakap, kreatif, mandiri, dan menjadi warga negara yang demokratis serta bertanggung jawab dalam rangka mencerdaskan kehidupan bangsa. Dengan kata lain diperlukan orang-orang yang berkualitas dan tangguh, serta peka terhadap perubahan dan pembaharuan sehingga mampu bersaing di era globalisasi seperti saat ini.

Terkait dengan dunia pendidikan, untuk menciptakan manusia yang berkualitas dan berprestasi tinggi maka siswa harus memliki prestasi belajar yang baik. Prestasi belajar merupakan indikator yang penting untuk mengukur keberhasilan proses belajar mengajar. Keberhasilan pendidikan merupakan tanggung jawab bersama antara keluarga (orang tua), anggota masyarakat dan pemerintah. Pemerintah dan masyarakat menyediakan tempat untuk belajar yaitu gedung sekolah.

Berdasarkan hasil observasi, pada jurusan Ilmu Pengetahuan Sosial (IPS) di SMA N 10 Kota Tangerang prestasi belajar siswa untuk mata pelajaran Ekonomi di kelas XI IPS SMA N 10 Kota Tangerang masih terbilang rendah. Kondisi ini ditunjukkan dengan masih banyak siswa yang belum memenuhi syarat nilai Kriteria Ketuntasan Minimal (KKM). Hal ini tentu menjadikan orang tua, guru dan siswa khawatir jika sampai ada siswa yang tidak lulus saat Ujian Kenaikan

$$
\text { Kelas (UKK). Sedangkan }
$$
pelaksanaan Ujian Kenaikan Kelas (UKK) semakin dekat.

\section{Pada saat Program Pengalaman} Lapangan (PPL) penulis melakukan evaluasi dan menghasilkan data sebagai berikut:

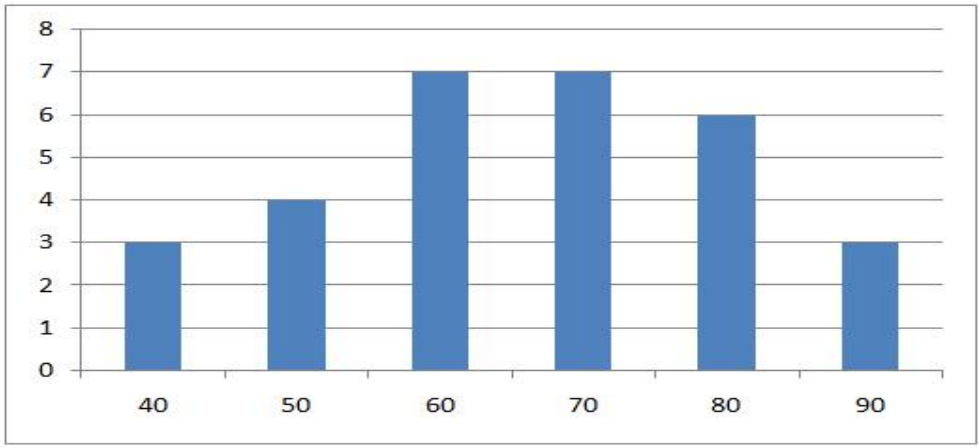

Gambar 1.1 Nilai Siswa

Sumber: Data hasil pra penelitian 
Berdasarkan hasil observasi yang dilakukan dapat diketahui bahwa siswa yang mendapat nilai 40 berjumlah 3 siswa $(10 \%)$, siswa yang mendapat nilai 50 berjumlah 4 siswa $(13,3 \%),(23,3 \%)$ siswa yang mendapat nilai 60 berjumlah 7 siswa, $(23,3 \%)$ siswa yang mendapat nilai 70 berjumlah 7 siswa, siswa yang mendapat nilai 80 berjumlah 6 siswa $(20 \%)$, siswa yang mendapat nilai 90 berjumlah 3 siswa $(10 \%)$. Dari data di atas dapat dilihat hampir $40 \%$ siswa nilainya di bawah KKM yang ditetapkan sebesar 65. Dapat disimpulkan bahwa prestasi belajar siswa kelas XI IPS SMA N 10 Kota Tangerang masih rendah khususnya pada mata pelajaran ekonomi. Saat penulis melakukan observasi pada bulan Maret 2018, guru ekonomi di SMA N 10 Kota Tangerang juga mengatakan bahwa nilai mata pelajaran ekonomi yang paling rendah pada mata pelajaran ranah IPS.

$$
\text { Prestasi belajar Ekonomi }
$$
merupakan salah satu indikator yang dapat dipakai untuk mengetahui keberhasilan belajar. Dengan prestasi belajar yang baik diharapkan dapat menggambarkan kualitas pendidikan yang baik pula. Orang tua memiliki pengaruh yang besar terhadap keberhasilan anak dalam perkembangan dan pendidikan anak. M. Dalyono, (2009: 59) berpendapat bahwa faktor orang tua berupa pendidikan orang tua, penghasilan orang tua, keakraban, serta perhatian dan bimbingan orang tua sangat berpengaruh pada perkembangan anak serta pencapaian hasil belajarnya. Bahar (dalam Maftukah, 2007), menyatakan bahwa: pada umumnya anak yang berasal dari keluarga menengah ke atas lebih banyak mendapatkan pengarahan dan bimbingan yang baik dari orang tua mereka. Anak-anak yang berlatar belakang ekonomi rendah, kurang mendapatkan bimbingan dan pengarahan yang cukup dari orang tua mereka, karena orang tua lebih mementingkan bagaimana cara untuk memenuhi kebutuhan sehari-hari.

Tingginya minat siswa-siswi sekolah formal mengikuti bimbingan belajar merupakan simbol ketidak percayaan siswa dan orang tua siswa terhadap proses pembelajaran di sekolah formal. Karenanya, sekolah harus memperbaiki pelayanannya kepada siswa untuk mengembalikan kepercayaan. Abu Ahmadi dan Supriyono Widodo, 2013: 111) tujuan pelayanan bimbingan belajar secara umum adalah membantu murid-murid agar mendapatkan penyesuaian yang baik di dalam situasi belajar, sehingga setiap murid dapat belajar dengan efisien sesuai kemampuan yang dimilikinya, mencapai perkembangan yang optimal.

Bimbingan belajar merupakan suatu proses bantuan yang diberikan kepada individu (siswa) untuk mengatasi masalah dalam belajar, agar setelah melaksanakan kegiatan belajar mengajar mereka dapat mencapai hasil belajar yang lebih baik sesuai kemampuan yang dimiliki masingmasing. 
Prestasi belajar merupakan hal yang tidak dapat dipisahkan dari kegiatan belajar, karena kegiatan belajar merupakan proses, sedangkan prestasi merupakan hasil dari proses belajar. Prestasi belajar merupakan ukuran keberhasilan yang diperoleh siswa selama proses belajarnya. Keberhasilan itu ditentukan oleh berbagai faktor yang saling berkaitan. Menurut Slameto, (2015: 54), faktor yang mempengaruhi prestasi belajar siswa terbagi dua, yaitu faktor Internal dan faktor Eksternal. Faktor Internal yang berasal dari dalam diri seseorang yang dapat mempengaruhi prestasi belajar. Minat adalah kecenderungan yang tetap untuk memperhatikan dan mengenal beberapa kegiatan. Kegiatan yang dimiliki seseorang diperhatikan terus menerus yang disertai dengan rasa sayang. Motivasi dalam belajar adalah faktor yang penting karena hal tersebut merupakan keadaan yang mendorong keadaan siswa untuk melakukan belajar. Persoalan mengenai motivasi dalam belajar adalah bagaimana cara mengatur agar motivasi dapat ditingkatkan. Demikian pula dalam kegiatan belajar mengajar sorang anak didik akan berhasil jika mempunyai motivasi untuk belajar. Faktor Eksternal yang berasal dari luar diri seseorang.

Faktor lingkungan sekolah, mempunyai pengaruh terhadap keberhasilan siswa dalam belajar karena hampir sepertiga dari kehidupan siswa sehari-hari berada disekolah. Faktor yang dapat menunjang keberhasilan adalah metode mengajar guru, kurikulum, relasi guru dengan siswa, relasi siswa dengan siswa, sarana dan prasarana pembelajaran, kedisiplinan waktu yang diterapkan.

Dari latar belakang di atas maka penulis tertarik untuk melakukan penelitian dengan judul "Pengaruh Status Sosial Ekonomi, dan Bimbingan Belajar Terhadap Prestasi Belajar Siswa Mata Pelajaran Ekonomi di SMA N 10 Kota Tangerang”.

\section{Identifikasi Masalah}

Berdasarkan uraian latar belakang di atas, dapat diidentifikasikan masalah sebagai berikut:

1.Apakah status sosial ekonomi berpengaruh terhadap prestasi belajar ekonomi di SMA N 10 Kota Tangerang?

2. Apakah bimbingan belajar berpengaruh terhadap prestasi belajar ekonomi di SMA N 10 Kota Tangerang?

3.Apakah siswa yang prestasinya rendah diduga karena kurang mendapat perhatian dari orang tuanya?

4. Apakah ada paksaan dari orang tua agar anaknya mengikuti bimbingan belajar diluar sekolah?

5.Apakah minat belajar berpengaruh terhadap prestasi belajar ekonomi di SMA N 10 Kota Tangerang?

6.Apakah motivasi belajar berpengaruh terhadap prestasi belajar ekonomi di SMA N 10 Kota Tangerang?

7.Apakah lingkungan sekolah berpengaruh terhadap prestasi belajar ekonomi di SMA N 10 Kota Tangerang? 


\section{Rumusan Masalah}

Berdasarkan latar belakang

masalah, identifikasi masalah dan batasan masalah di atas, maka dalam penelitian ini dapat ditentukan rumusan masalah sebagai berikut:

1. Apakah status sosial ekonomi berpengaruh terhadap prestasi belajar siswa mata pelajaran ekonomi kelas XI program IPS di SMA N 10 Kota Tangerang?

2. Apakah bimbingan belajar berpengaruh terhadap prestasi belajar siswa mata pelajaran ekonomi kelas XI program IPS di SMA N 10 Kota Tangerang?

3. Apakah status sosial ekonomi dan bimbingan belajar berpengaruh bersamasama terhadap prestasi belajar siswa mata pelajaran ekonomi kelas XI program IPS di SMA N 10 Kota Tangerang?

\section{Tujuan Penelitian}

Penelitian ini adalah untuk mengetahui pengaruh:

1. Pengaruh status sosial ekonomi terhadap prestasi belajar siswa mata pelajaran ekonomi kelas XI program IPS di SMA N 10 Kota Tangerang.

2. Pengaruh bimbingan belajar di luar sekolah terhadap prestasi belajar siswa mata pelajaran ekonomi kelas XI program IPS di SMA N 10 Kota Tangerang.

3. Pengaruh status sosial ekonomi dan bimbingan belajar di luar sekolah terhadap prestasi belajar siswa mata pelajaran ekonomi kelas XI program IPS di SMA N 10 Kota Tangerang.

\section{KAJIAN PUSTAKA}

Prestasi Belajar

Prestasi berasal dari kata achievement yang berarti bahwa hasil yang telah dicapai atau dengan kata lain satu tingkat khusus dari kesuksesan karena mempelajari tingkat tertentu dari sebuah kecakapan atau keahlian dalam tugas-tugas sekolah atau akademis. Dalam bidang akademis, prestasi belajar sering diartikan sebagai satu tingkat khusus perolehan atau hasil keahlian dalam karya akademis yang dinilai oleh guru-guru melalui tes-tes yang dibakukan. (Chaplin J.P, 2015: 5).

Menurut Sumardi Suryabrata, (2006: 297), prestasi adalah nilai yang merupakan perumusan terakhir yang dapat diberikan oleh guru mengenai kemajuan atau prestasi belajar siswa selama masa tertentu.

Berdasarkan kesimpulan dari berbagai pendapat di atas, dapat disimpulkan bahwa prestasi adalah hasil dari usaha atau tingkat keberhasilan siswa dalam mencapai tujuan yang dapat diberikan oleh guru mengenai kemajuan belajar siswa selama masa tertentu dan nilai-nilai yang terdapat dalam kurikulum. Dengan adanya prestasi tersebut, maka siswa dapat melihat seberapa jauh kemampuan yang diperolehnya dalam proses belajar mengajar. 
Menurut Slameto, (2015: 54) faktorfaktor yang mempengaruhi prestasi belajar adalah sebagai berikut:

(1) Faktor Intern yang meliputi: faktor jasmaniah, faktor psikologis dan faktor kelelahan. (2) Faktor Ekstern yang meliputi: faktor keluarga, faktor sekolah dan faktor masyarakat.

\section{Kondisi Sosial Ekonomi}

Keadaan sosial ekonomi setiap orang itu berbeda-beda dan bertingkat, ada yang keadaan sosial ekonominya tinggi, sedang, dan rendah. Status sosial ekonomi adalah kedudukan atau posisi seseorang dalam masyarakat, status sosial ekonomi adalah gambaran tentang keadaan seseorang atau suatu masyarakat yang ditinjau dari segi sosial ekonomi, gambaran itu seperti tingkat pendidikan, pendapatan dan sebagainya. Status ekonomi kemungkinan besar merupakan pembentuk gaya hidup keluarga. Pendapatan keluarga memadai akan menunjang tumbuh kembang anak. Karena orang tua dapat menyediakan semua kebutuhan anak baik primer maupun skunder (Soetjiningsih, 2004). Sedangkan menurut Hamalik dalam Rosihan (2014) bahwa keadaan sosial ekonomi yang baik dapat yang menghambat ataupun mendorong dalam belajar. Masalah biaya pendidikan juga merupakan sumber kekuatan dalam belajar karena kurangnya biaya pendidikan akan sangat mengganggu kelancaran belajar. Salah satu fakta yang mempengaruhi tingkat pendidikan anak adalah pendapatan keluarga.

Berdasarkan beberapa pendapat diatas, dapat disimpulkan pengertian keadaan sosial ekonomi dalam penelitian ini adalah kedudukan atau posisi seseorang dalam masyarakat berkaitan dengan tingkat pendidikan, tingkat pendapatan pemilikan kekayaan atau fasilitas serta jenis tempat tinggal.

Menurut Abdulsyani, (1994) ada beberapa faktor yang dapat menentukan tinggi rendahnya keadaan sosial ekonomi orang tua di masyarakat, diantaranya (1) tingkat pendidikan, (2) jenis pekerjaan, (3) tingkat pendapatan, (4) kondisi lingkungan tempat tingal, (5) pemilikan kekayaan, dan (6) partisipasi dalam aktivitas kelompok dari komunitasnya. Dalam hal ini uraiannya dibatasi hanya 4 faktor yang menentukan yaitu tingkat pendidikan, pendapatan, dan kepemilikan kekayaan, dan jenis tempat tinggal.

\section{Bimbingan Belajar}

Nana Syaodih Sukmadinata, (2007: 6) berpendapat bahwa bimbingan (guidance) merupakan salah satu bidang dan program dari pendidikan yang ditujukan untuk membantu mengoptimalkan perkembangan siswa. Bimbingan merupakan upaya yang ditempuh untuk membantu para siswa mengoptimalkan perkembangan potensi dan kecakapannya. Perkembangan tersebut mencakup seluruh aspek kepribadian siswa, 
aspek fisik motorik, intelektual, sosial dan afektif.

Sedangkan Dewa Ketut Sukardi, (2008: 37) berpendapat bahwa bimbingan adalah proses pemberian bantuan kepada seseorang atau sekelompok orang yang secara terus menerus dan sistematis oleh seorang pembimbing atau tentor agar seorang individu atau sekelompok individu tersebut bisa menjadi pribadi yang mandiri.

Dari pengertian bimbingan dan belajar di atas, dapat diambil kesimpulan bahwa bimbingan belajar (bimbel) merupakan suatu program kegiatan yang dilakukan sebagai upaya membantu siswa untuk mengembangkan pengetahuan dan ketrampilan yang dimiliki. Sedangkan bimbel di luar sekolah merupakan program bimbingan belajar yang dilakukan oleh pihak di luar sekolah. Bimbel yang dimaksud adalah bimbel yang dilakukan oleh perorangan (privat) ataupun bimbel yang dilakukan oleh lembaga.

\section{Penelitian Terdahulu}

Dwi Cahyo Adhi (2014) dalam penelitiannya mengenai Pengaruh Status Sosial Ekonomi dan Bimbingan Belajar Terhadap Prestasi Belajar Siswa Mata Pelajaran Ekonomi di SMAN 1 Jogonalan. Hasil Penelitian menunjukkan bahwa status sosial ekonomi dan bimbingan belajar secara simultan berpengaruh positif dan signifikan terhadap prestasi belajar siswa mata pelajaran ekonomi di SMAN 1 Jogonalan.

\section{Kerangka Berpikir}

Status sosial ekonomi (X1), dan Bimbingan belajar diluar sekolah (X2) merupakan variabel bebas (independent variabel). Sedangkan Prestasi belajar (Y) merupakan variabel terikat (dependent variabel). Pada penelitian ini akan menguji atau mencari ada atau tidaknya pengaruh antara variabel bebas dengan variabel terikat. Kerangka yang dimaksud dapat ditunjukkan pada gambar berikut:

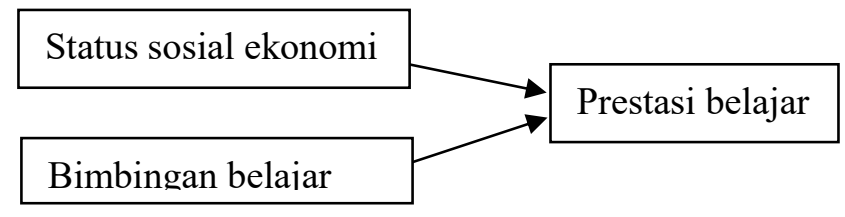

Gambar 1

\section{Hipotesis}

Berdasarkan landasan teori dan kerangka pikir yang telah penulis uraikan maka penulis merumuskan hipotesis sebagai berikut:
1. Ada pengaruh positif dan signifikan status sosial ekonomi terhadap prestasi belajar siswa mata pelajaran ekonomi kelas XI program IPS di SMAN 10 Kota Tangerang. 
2. Ada pengaruh positif dan signifikan bimbingan belajar terhadap prestasi belajar siswa mata pelajaran ekonomi kelas XI program IPS di SMAN 10 Kota Tangerang.

3. Ada pengaruh positif dan signifikan status sosial ekonomi dan bimbingan belajar terhadap prestasi belajar siswa mata pelajaran ekonomi kelas XI program IPS di SMAN 10 Kota Tangerang.

\section{B. METODE PENELITIAN}

\section{Pendekatan Penelitian}

Penelitian ini merupakan penelitian ex-post facto. Sedangkan jika ditinjau dari paradigmanya, penelitian ini termasuk penelitian kuantitatif. Penelitian kuantitatif merupakan penelitian yang menekankan pengujian teori melalui pengukuran variabel-variabel penelitian dengan angka dan melakukan analisis data berdasarkan prosedur statistik.

\section{Populasi dan Sampel}

Dalam penelitian ini yang menjadi populasi adalah peserta didik kelas X IPS di SMAN 10 Kota Tangerang yang berjumlah 116 orang.

Sampel yang digunakan yaitu jenis probability sampling dan yang digunakan dalam pengambilan sampel pada penelitian ini adalah simple random sampling. jumlah sampel dalam penelitian ini adalah sebanyak 54 siswa di SMAN 10 Kota Tangerang.

\section{Teknik Pengumpulan Data}

Peneliti menggunakan beberapa metode untuk mempermudah penelitian ini, yaitu angket atau kuesioner dan dokumentasi.

\section{Teknik Analisis Data}

Teknik analisis yang digunakan ialah terdiri dari uji prasyarat analisis, analisis data, uji validitas, dan uji reliabilitas.

\section{Uji Instrumen Penelitian}

\section{a. Uji Validitas}

Setelah melakukan uji instrumen didapatkan hasil dari 22 soal pilihan ganda Status Sosial Keluarga dinyatakan 18 soal valid dan 4 soal tidak valid di drop atau tidak digunakan. Dan hasil dari 18 soal pilihan ganda Bimbingan Belajar dinyatakan 13 soal valid dan 5 soal tidak valid di drop atau tidak digunakan.

\section{b. Uji Reliabilitas}

Setelah melakukan uji reliabilitas didapatkan hasil diatas bahwa variabel status sosial ekonomi dengan 22 butir soal sebesar 0,865 . Variabel bimbingan belajar 18 butir sebesar 0,685. Yang berarti masing-masing variabel reliabel.

\section{Uji Prasyarat Analisis}

Uji prasayarat analisis terdiri dari uji normalitas dan uji linearitas. 


\section{Uji Asumsi Klasik}

Model regresi linier dapat disebut sebagai model yang baik jika model tersebut memenuhi beberapa asumsi klasik yaitu, tidak adanya multikolinieritas dan heteroskedastisitas. Harus terpenuhinya asumsi klasik ini agar diperoleh model regresi dengan estimasi yang tidak bias dan pengujiannya dapat dipercaya.

\section{Analisis Data}

Analisis data yang digunakan yaitu analisis regresi linear berganda dan koefisien determinasi $\left(\mathrm{R}^{2}\right)$.

\section{Hipotesis Statistik}

\section{a. Pengujian Secara Parsial (Uji T) \\ b. Pengujian Secara Serempak (Uji F)}

\section{HASIL DAN PEMBAHASAN}

\section{Hasil Pengujian}

\section{a. Uji Validitas dan Uji Reliabilitas}

Berdasarkan penelitian yang telah dilakukan didapatkan hasil dari 22 soal pilihan ganda Status Sosial Ekonomi dinyatakan 18 soal valid dan 4 soal tidak valid di drop atau tidak digunakan. Dan hasil dari 18 soal pilihan ganda Bimbingan Belajar dinyatakan 13 soal valid dan 5 soal tidak valid di drop atau tidak digunakan.

\section{b. Uji Reliabilitas}

Berdasarkan penelitian yang telah dilakukan didapatkan hasil bahwa variabel status sosial ekonomi dengan 22 butir soal sebesar 0,865. Variabel bimbingan belajar 18 butir sebesar 0,685 . Yang berarti masingmasing variabel reliabel.

\section{c. Uji Normalitas}

Tabel 3

Hasil Uji Normalitas

Chi-Square Tests

\begin{tabular}{|l|r|r|r|}
\hline & \multicolumn{1}{|c|}{ Value } & df & \multicolumn{1}{c|}{$\begin{array}{c}\text { Asymp. Sig. } \\
\text { (2-sided) }\end{array}$} \\
\hline Pearson Chi-Square & $352,695^{\mathrm{a}}$ & 345 &, 376 \\
Likelihood Ratio & 181,974 & 345 & 1,000 \\
Linear-by-Linear & 1,408 & 1 &, 235 \\
Association & 54 & & \\
N of Valid Cases & & \\
\hline
\end{tabular}

Sumber : Data output SPSS Statistic 22

Bila harga signifikansi lebih kecil dari pada 0,1, maka distibusi data dinyatakan tidak normal, dan bila lebih besar $(>)$ dinyatakan normal. Berdasarkan Tabel 4 diketahui nilai signifikansi diperoleh $0,376>0,1$ maka data dinyatakan normal. 


\section{d. Uji Linearitas}

Tabel 4

Hasil Uji Linearitas

ANOVA Table

\begin{tabular}{|c|c|c|c|c|c|c|}
\hline & & $\begin{array}{l}\text { Sum of } \\
\text { Squares }\end{array}$ & $\mathrm{df}$ & $\begin{array}{c}\text { Mean } \\
\text { Squar } \\
\text { e }\end{array}$ & $\mathrm{F}$ & Sig. \\
\hline \multirow[t]{3}{*}{$\begin{array}{l}\text { Between } \\
\text { Groups }\end{array}$} & $\begin{array}{l}\text { (Combin } \\
\text { ed) }\end{array}$ & $\begin{array}{r}1976,71 \\
4\end{array}$ & 16 & $\begin{array}{r}123,54 \\
5\end{array}$ & 1,536 & ,139 \\
\hline & Linearity & 40,882 & 1 & 40,882 & ,508 &, 480 \\
\hline & $\begin{array}{l}\text { Deviatio } \\
\mathrm{n} \text { from } \\
\text { Linearity }\end{array}$ & $\begin{array}{r}1935,83 \\
2\end{array}$ & 15 & $\begin{array}{r}129,05 \\
5\end{array}$ & 1,604 &, 120 \\
\hline \multicolumn{2}{|c|}{ Within Groups } & $\begin{array}{r}2976,71 \\
2 \\
\end{array}$ & 37 & 80,452 & & \\
\hline \multicolumn{2}{|l|}{ Total } & $\begin{array}{r}4953,42 \\
6\end{array}$ & 53 & & & \\
\hline
\end{tabular}

Sumber : Data output SPSS Statistic 22

Dari output diatas, hasil uji maka dapat disimpulkan bahwa antara linearitas dapat dilihat pada output ANOVA variabel Prestasi Belajar dan Bimbingan Table. Dari Tabel 4 dapat diketahui bahwa Belajar terdapat hubungan yang linear. nilai signifikansi pada Linearity sebesar e. Uji Multikolinearitas 0,480. Karena signifikansi lebih dari 0,1,

Tabel 5

Hasil Uji Multikolinearitas

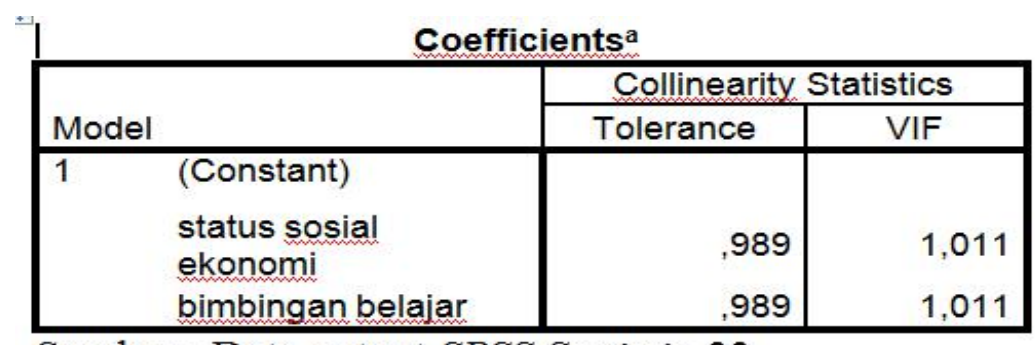

Sumber : Data output SPSS Statistic 22

Dari output diatas dapat diketahui bahwa nilai Tolerance kedua variabel lebih dari 0,10 dan VIF kurang dari 10, maka dapat disimpulkan bahwa tidak terjadi Multikolinearitas antar variabel bebas. 


\section{f. Uji Heteroskedastisitas}

Tabel 6

Hasil Uji Heteroskedastisitas

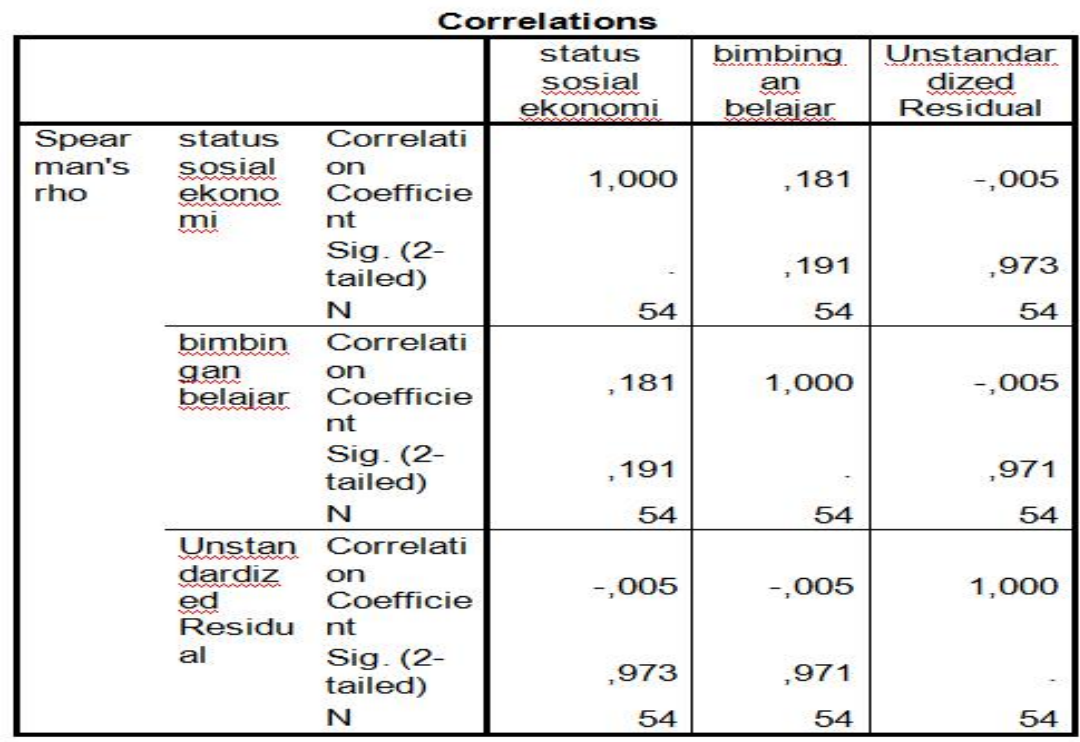

Sumber : Data output SPSS Statistic 22

Dari hasil output diatas dapat dilihat bahwa korelasi antara variabel Bimbingan Belajar dan Status Sosial Ekonomi dengan Unstandartdized Residual memiliki signifikansi (Sig 2-tailed) lebih dari 0,1.
Karena signifikansi lebih besar dari 0,1 maka dapat disimpulkan tidak terjadi masalah Heteroskedastisitas.

g. Estimasi Regresi Berganda

Tabel 7

Hasil Estimasi Regresi Berganda Coefficients $^{a}$

\begin{tabular}{|c|c|c|c|c|c|}
\hline \multirow[b]{2}{*}{ Model } & \multicolumn{2}{|c|}{$\begin{array}{l}\text { Unstandardized } \\
\text { Coefficients }\end{array}$} & \multirow{2}{*}{$\begin{array}{c}\begin{array}{c}\text { Standardized } \\
\text { Coefficients }\end{array} \\
\text { Beta }\end{array}$} & \multirow[b]{2}{*}{$\mathrm{t}$} & \multirow[b]{2}{*}{ Sig. } \\
\hline & B & $\begin{array}{l}\text { Std. } \\
\text { Error }\end{array}$ & & & \\
\hline 1 (Constant) & $\begin{array}{r}100,50 \\
7\end{array}$ & 18,889 & & 5,321 & ,000 \\
\hline $\begin{array}{l}\text { status } \\
\text { sosial } \\
\text { ekonomi }\end{array}$ & ,241 & 179, & , 178 & 1,347 & , 184 \\
\hline $\begin{array}{l}\text { bimbingan } \\
\text { belajar }\end{array}$ &,- 982 & ,439 &,- 295 & $-2,235$ &, 030 \\
\hline
\end{tabular}

Sumber : Data output SPSS Statistic 22

Nilai-nilai pada output kemudian dimasukkan ke dalam persamaan regresi linier berganda sebagai berikut:

$$
Y=100,507+0,241 X_{1}-0,982 X_{2}
$$

Arti dari angka-angka ini adalah sebagai berikut: 
a. Nilai kosntanta (a) adalah 100,507 ; ini dapat diartikan jika Bimbingan Belajar dan Status Sosial Ekonomi nilainya adalah 0, maka Prestasi Belajar nilainya 100,507 .

b. Nilai koefisien regresi variabel Status Sosial Ekonomi $\left(b_{1}\right)$ bernilai positif, yaitu 0,241 ; ini dapat diartikan bahwa setiap peningkatan Status Sosial Ekonomi sebesar 1 satuan, maka akan meningkatkan Prestasi Belajar sebesar
0,241 satuan dengan asumsi variabel independen dan nilainya tetap.

c. Nilai koefisien regresi variabel Bimbingan Belajar $\left(b_{2}\right)$ bernilai negatif, yaitu $-0,982$; ini dapat diartikan bahwa setiap peningkatan Bimbingan Belajar sebesar 1 satuan, maka akan menurunkan Prestasi Belajar sebesar 0,982 satuan dengan asumsi variabel independen lain nilainya tetap.

\section{h. Estimasi Koefisien Determinasi}

Tabel 8

Hasil Estimasi Koefisien Determinasi

\begin{tabular}{|c|c|c|c|c|}
\hline \multicolumn{5}{|c|}{ Model Summary b } \\
\hline Model & $R$ & $\begin{array}{c}R \\
\text { Square }\end{array}$ & $\begin{array}{l}\text { Adjusted R } \\
\text { Square }\end{array}$ & $\begin{array}{l}\text { Std. Error of } \\
\text { the Estimate }\end{array}$ \\
\hline 1 &, $337^{a}$ &, 113 &, 079 & 9,280 \\
\hline
\end{tabular}

Sumber : Data output SPSS Statistic 22

Berdasarkan tabel tersebut dapat diketahui nilai $\mathrm{R}$ Square sebesar 0,113 , hal ini menunjukkan bahwa persentase sumbangan pengaruh variabel secara bersama sama sebesar $11,3 \%$. Atau variasi varibel independen yang digunakan dalam model mampu menjelaskan sebesar 11,3\% variasi variabel dipenden. Sedangkan sisanya sebesar $88,7 \%$ dipengaruhi atau dijelakan oleh variabel lain yang tidak dimasukkan dalam penelitian ini. 


\section{i. Uji T}

\section{Tabel 9}

Uji T

Coefficients ${ }^{a}$

\begin{tabular}{|c|c|c|c|c|c|}
\hline \multirow[b]{2}{*}{ Model } & \multicolumn{2}{|c|}{$\begin{array}{c}\text { Unstandardized } \\
\text { Coefficients }\end{array}$} & \multirow{2}{*}{$\begin{array}{c}\begin{array}{c}\text { Standar } \\
\text { dized } \\
\text { Coefficie } \\
\text { nts }\end{array} \\
\text { Beta } \\
\end{array}$} & \multirow[b]{2}{*}{$t$} & \multirow[b]{2}{*}{ Sig. } \\
\hline & $B$ & $\begin{array}{c}\text { Std. } \\
\text { Error }\end{array}$ & & & \\
\hline $\begin{array}{l}\text { (Const } \\
\text { ant) }\end{array}$ & 100,507 & 18,889 & & 5,321 & , 000 \\
\hline $\begin{array}{l}\text { status } \\
\text { sosial } \\
\text { ekonomi }\end{array}$ & ,241 & 179 & , 178 & 1,347 & , 184 \\
\hline $\begin{array}{l}\text { bimbinga } \\
\text { n belajar }\end{array}$ &,- 982 & ,439 &,- 295 & $-2,235$ & , 030 \\
\hline
\end{tabular}

Sumber: Data output SPSS Statistic 22

Kriteria pengujian yang digunakan

Ho ditolak jika $\mathrm{T}_{\text {hitung }}>\mathrm{T}_{\text {tabel }}(1,675)$ atau $\mathrm{T}_{\text {hitung }}<-\mathrm{T}_{\text {tabel }}(-1,675)$ dan dengan melihat nilai signifikansi $<0,1$, dan $\mathrm{Ho}$ diterima jika $-\mathrm{T}_{\text {tabel }}<\mathrm{T}_{\text {hitung }}<\mathrm{T}_{\text {tabel. }}$ dan dengan melihat nilai signifikansi $>0,1$

Berdasarkan tabel diatas diketahui bahawa nilai $\mathrm{T}$ hitung pada status sosial ekonomi sebesar 1,347 dan nilai $\mathrm{T}_{\text {tabel }}$ 1,675 dapat disimpulkan bahwa nilai $\mathrm{T}$ hitung lebih kecil dari $\mathrm{T}_{\text {tabel }}$ dan nilai signifikansi $0,184>$ 0,1 , yang artinya status sosial ekonomi orang tua tidak berpengaruh terhadap prestasi belajar. Hasil penelitian ini sesuai dengan penelitian yang dilakukan oleh Diah Arumsasi (2014) bahwa status sosial ekonomi orang tua tidak berpengaruh terhadap prestasi belajar.

Pada tabel diatas nilai $\mathrm{T}$ hitung pada Bimbingan Belajar diketahui sebesar -2,235 dan nilai $T$ tabel sebesar 1,675 dan nilai signifikansi sebesar $0,030<0,1$ maka dapat disimpulkan bahwa nilai $-\mathrm{T}$ hitung $<-\mathrm{T}$ tabel yang artinya $\mathrm{Ho}$ ditolak dan $\mathrm{Ha}$ diterima. Jadi dapat disimpulkan bahwa Bimbingan Belajar berpengaruh terhadap Prestasi Belajar. Hasil ini sesuai dengan penelitian Andi Thahir (2014) yang menyatakan bahwa Bimbingan Belajar berpengaruh Terhadap Prestasi Belajar. 


\section{j. Uji F}

\section{Tabel 10}

Uji F

ANOVA $^{a}$

\begin{tabular}{|l|r|r|r|r|r|}
\hline Model & $\begin{array}{c}\text { Sum of } \\
\text { Squares }\end{array}$ & df & $\begin{array}{c}\text { Mean } \\
\text { Square }\end{array}$ & F & Sig. \\
\hline 1 Regression & 561,842 & 2 & 280,921 & 3,262 & $\begin{array}{r}046 \\
\text { b }\end{array}$ \\
Residual & 4391,584 & 51 & 86,109 & & \\
Total & 4953,426 & 53 & & & \\
\hline
\end{tabular}

Sumber : Data output SPSS Statistic 22

Kriteria pengujian yang digunakan

Ho ditolak jika $\mathrm{F}$ hitung $>\mathrm{F}$ tabel $(2,41))$ dan dengan melihat nilai signifikansi $<0,1$. Ho diterima jika $\mathrm{F}$ hitung $<\mathrm{F}$ tabel $(2,41)$. ) dan dengan melihat nilai signifikansi $>0,1$.

Berdasarkan tabel tersebut dapat diketahui bahwa nilai $\mathrm{F}$ Hitung sebesar 3,262 dengan $\mathrm{F}$ Tabel sebesar 2,41 maka $\mathrm{F}$ Hitung lebih besar dari $\mathrm{F}$ Tabel dan nilai signifikansi $0,046<0,1$ yang artinya variabel independen secara bersama-sama berpengaruh terhadap variabel dipenden.

\section{PEMBahasan}

\section{Pengaruh Status Sosial Ekonomi}

Dalam penelitian ini diperoleh hasil bahwa Status Sosial Ekonomi (X1) secara parsial tidak berpengaruh terhadap Prestasi Belajar (Y). Hal ini didasarkan pada hasil uji $\mathrm{T}$ hitung lebih kecil dari $\mathrm{T}$ tabel yaitu nilai $\mathrm{T}$ hitung nya sebesar 1,347 dan nilai $\mathrm{T}_{\text {tabel }} 1,675$ dapat disimpulkan bahwa nilai $\mathrm{T}$ hitung lebih kecil dari $\mathrm{T}$ tabel dan nilai signifikansi 0,184 $>0,1$. Maka dapat disimpulkan bahwa $H o$ diterima dan $\mathrm{Ha}$ ditolak. Ini menunjukan bahwa koefisien regresi pada variabel Status Sosial Ekonomi positif dan tidak signifikan. Artinya Status Sosial Ekonomi secara parsial tidak berpengaruh terhadap prestasi belajar siswa. Karena, keadaan ekonomi orang tua tidak menjamin prestasi belajar siswa baik. Hasil penelitian ini sesuai dengan penelitian yang dilakukan oleh Diah Arumsasi (2014) bahwa status sosial ekonomi orang tua tidak berpengaruh terhadap prestasi belajar.

\section{Pengaruh Bimbingan Belajar}

Dalam penelitian ini diperoleh hasil bahwa Bimbingan Belajar (X2) secara parsial berpengaruh terhadap Prestasi Belajar (Y). Hal ini didasarkan pada hasil uji $\mathrm{T}$ hitung lebih kecil dari $\mathrm{T}$ tabel yaitu nilai $\mathrm{T}$ hitung nya sebesar $-2,235$ dan nilai $T$ tabel 1,675 dapat disimpulkan bahwa nilai $\mathrm{T}$ hitung lebih kecil dari $\mathrm{T}$ tabel dan nilai signifikansi sebesar $0,030<0,1$ maka dapat disimpulkan bahwa nilai $-\mathrm{T}_{\text {hitung }}<-\mathrm{T}$ tabel yang artinya Ho ditolak dan $H a$ diterima. Jadi dapat disimpulkan bahwa Bimbingan Belajar 
berpengaruh terhadap Prestasi Belajar. Jadi apabila siswa rajin mengikuti Bimbingan Belajar diluar sekolah maka prestasi belajarnya akan baik. Hasil ini sesuai dengan penelitian Andi Thahir (2014) yang menyatakan bahwa Bimbingan Belajar berpengaruh Terhadap Prestasi Belajar.

\section{Pengaruh Status Sosial Ekonomi dan Bimbingan Belajar}

Berdasarkan hasil uji secara simultan menunjukkan bahwa status sosial ekonomi dan bimbingan belajar berpengaruh terhadap prestasi belajar siswa. Hal ini didasarkan pada hasil penelitian yang menunjukkan bahwa nilai $\mathrm{F}$ Hitung sebesar 3,262 dengan $F$ Tabel sebesar 2,41 dan nilai signifikansi $0,046<0,1$ yang artinya variabel independen secara bersamasama berpengaruh terhadap variabel dipenden. Besarnya pengaruh status sosial ekonomi $\left(\mathrm{X}_{1}\right)$ dan Bimbingan Belajar $\left(\mathrm{X}_{2}\right)$ terhadap Prestasi Belajar (Y) 11,3\% sedangkan sisanya sebesar $\quad 88,7 \%$ dipengaruhi atau dijelakan oleh variabel lain yang tidak dimasukkan dalam penelitian ini. Hasil ini sesuai dengan penelitian yang dilakukan oleh Dwi Cahyo Adhi (2015).

\section{Keterbatasan Penelitian}

Penulis menyadari bahwa dalam melakukan penelitian ini masih banyak kekurangan dan ketidak sempurnaan. Penulis telah berupaya semaksimal mungkin agar penelitian ini memperoleh hasil optimal.
Akan tetapi terdapat beberapa hal yang sulit dikendalikan yang menjadi keterbatasan penulis dalam melakukan penelitian ini, diantarannya sebagai berikut:

1. Ketidaksesusaian pengumpulan data pada variabel status sosial yang menggunakan angket sehingga peneliti tidak dapat mengintrol jawaban responden yang tidak menunjukkan kenyataan yang sesungguhnya.

2. Variabel prestasi belajar siswa hanya dilihat dari aspek kognitif saja yaitu nilai ulangan harian. Nilai tersebut mungkin belum menggambarkan kemampuan siswa seutuhnya.

3. Terdapat banyak faktor yang mempengaruhi prestasi belajar, sementara penelitian ini hanya melibatkan dua variabel saja yaitu status sosial ekonomi dan bimbingan belajar.

Meskipun variabel bebas dan variabel terikat terdapat pengaruh, tetapi besarnya sumbangan hanya sebesar $11,3 \%$ sehingga masih ada $88,7 \%$ dari faktor lain yang tidak diteliti dalam penelitian ini. Hal ini menunjukkan bahwa dua variabel yang diteliti belum dapat menjelaskan secara menyeluruh mengenai faktor-faktor yang mempengaruhi prestasi belajar ekonomi 


\section{E. KESIMPULAN，IMPLIKASI，DAN SARAN}

\section{Kesimpulan}

Berdasarkan pembahasan yang telah diuraikan sebelumnya, maka diperoleh kesimpulan sebagai berikut :

1. Tidak terdapat pengaruh status sosial ekonomi orang tua terhadap prestasi belajar ekonomi. Hal tersebut dapat ditunjukkan dengan nilai T sebesar 1,347, koefisien regresi $\left(b_{1}\right)$ sebesar 0,421 dan nilai signifikansi sebesar $0,184>0,1$

2. Terdapat berpengaruh signifikan bimbingan belajar di luar sekolah terhadap prestasi belajar ekonomi. Hal tersebut dapat ditunjukkan dengan nilai $\mathrm{t}$ sebesar -2,235, koefisien regresi $\left(b_{2}\right)$ sebesar $-0,982$ dan nilai signifikansi sebesar $0,030<0,1$.

3. Terdapat pengaruh positif dan signifikan status sosial ekonomi orang tua dan bimbingan belajar di luar sekolah terhadap prestasi belajar ekonomi. Hal ini ditunjukkan dengan nilai $\mathrm{F}$ sebesar 3,42 dengan nilai signifikansi sebesar $0,046<0,1$. Nilai koefisien determinasi $\left(\mathrm{R}^{2}\right)$ sebesar 0,113 atau $11,3 \%$. Nilai $\mathrm{R}^{2}$ tersebut menunjukkan $11,3 \%$ prestasi belajar ekonomi dapat dijelaskan oleh variabel status sosial ekonomi dan bimbingan belajar di luar sekolah, sedangkan sisanya sebesar $88,7 \%$ dijelaskan oleh variabel lain yang tidak diteliti dalam penelitian ini.

\section{Implikasi}

Prestasi belajar dapat dipengaruhi banyak hal salah satunya adalah melalui Bimbingan belajar. Dalam hasil penelitian ini menunjukkan bahwa Bimbingan Belajar berpengaruh signifikan terhadap prestasi belajar. Hal mengindikasi bahwa bimbingan belajar sangat penting bagi siswa dalam meningkatkan prestasi belajar. Maka dari itu setiap orang tua perlu mengawasi anakanaknya agar fokus mengikuti bimbingan belajar di luar sekolah agar prestasi belajar tidak mengalami penurunan.

\section{Saran}

Berdasarkan pembahasan, kesimpulan di atas maka dapat diberikan saran sebagai berikut:

1. Sesuai dengan kesimpulan pertama bahwa tidak terdapat pengaruh positif dan signifikan status sosial ekonomi terhadap prestasi belajar, maka saran yang bisa disampaikan kepada para orang tua siswa yaitu tidak cukup hanya dengan memenuhi kebutuhan materi saja, tetapi juga lebih meningkatkan perhatian kepada anak terutama dalam kegiatan belajar supaya prestasi belajar siswa meningkat.

2. Sesuai dengan kesimpulan kedua yaitu terdapat pengaruh signifikan bimbingan belajar di luar sekolah terhadap prestasi belajar, maka saran yang bisa disampaikan kepada siswa yaitu lebih meningkatkan intensitas belajarnya 
dengan mengikuti bimbingan belajar di luar sekolah baik yang diselenggarakan oleh lembaga maupun privat.

3. Sesuai dengan kesimpulan ketiga yaitu terdapat pengaruh positif dan signifikan status sosial ekonomi dan bimbingan belajar di luar sekolah terhadap prestasi belajar ekonomi, maka saran yang dapat disampaikan bagi peneliti selanjutnya perlu memasukkan variabel-variabel lain selain dua variabel yang diteliti dalam penelitian ini. Hal ini mengacu pada hasil penelitian yang menunjukkan bahwa terdapat pengaruh status sosial ekonomi dan bimbingan belajar di luar sekolah berpengaruh terhadap prestasi belajar ekonomi sebesar 11,3\%. Hal ini menunjukkan bahwa prestasi belajar ekonomi masih banyak dipengaruhi oleh faktor-faktor lain yang tidak diteliti dalam penelitian ini.

Bagi sekolah hendaknya membantu menyediakan fasilitas belajar dan beasiswa bagi siswa berprestasi yang berasal dari keluarga kurang mampu.

\section{REFERENSI}

Abdulsyani. (1994). Sosiologi Skematika, Teori dan Terapan. Jakarta: Bumi Aksara.

Abu Ahmadi dan Supriyono Widodo. (2013). Psikologi Belajar. PT Rineka Cipta.

Adhi, D.C., Muhson, A. (2016). Pengaruh Status Sosial Ekonomi dan Bimbingan Belajar Terhadap Prestasi Belajar Siswa Mata Pelajaran Ekonomi di SMAN 1 Jogonalan. Jurnal Pendidikan Universitas Negeri Yogyakarta.

Chaplin, J.P.. 2015. Kamus Lengkap Psikologi. Jakarta: Rajagrafindo Persada.

Chotimah, L.N., Ani, H.M., Widodo, K. (2017). Pengaruh Status Sosial Ekonomi Orang Tua Terhadap Prestasi Belajar Siswa. Jurnal Pendidikan Ekonomi Universitas Jember.

Dewa Ketut Sukardi. (2008b). Pengantar Pelaksanaan Program Bimbingan dan Konseling di Sekolah. Jakarta: PT Rineka Cipta.

M. Dalyono. (2009). Psikologi Pendidikan. Jakarta: PT Rineka Cipta.

Nana Syaodih Sukmadinata. (2007). Bimbingan dan Konseling dalam Praktek. Bandung: Maestro.

Prabawa, K.A., Dunia, K., Haris, I.K. (2014). Pengaruh Sosial Ekonomi dan Perhatian Orang Tua Terhadap Prestasi Belajar Ekonomi Siswa Kelas X4. Jurnal Pendidikan Ekonomi Universitas Pendidikan Ganesha

Slameto. (2015). Belajar dan Faktor-faktor yang Mempengaruhinya. Jakarta: PT Rineka Cipta. 